\title{
CLIMA URBANO EM JALES/SP: ANÁLISE DO CAMPO TÉRMICO E HIGROMÉTRICO PARA OS MESES DE JANEIRO E JULHO DE 2010
}

\author{
UGEDA JUNIOR, José Carlos - ugedajunior@gmail.com \\ FCT/UNESP, Presidente Prudente-SP \\ TRINDADE AMORIM, Margarete Cristiane de Costa - mccta@fct.unesp.br \\ FCT/UNESP, Presidente Prudente-SP
}

\begin{abstract}
RESUMO: A partir da década de 1960, ocorreram alterações nas relações de trabalho no campo e na cidade, que tiveram como consequências o êxodo rural e o crescimento das cidades brasileiras, sendo que a cidade de Jales-SP, também se insere neste contexto. As alterações nas características naturais provocadas pela urbanização e, acentuadas pelo planejamento inadequado, resultam em diversas modificações no ambiente urbano. O clima é um dos componentes do ambiente que também está sujeito a essas mudanças. Dessa maneira, o presente artigo tem como objetivo apresentar as características da temperatura e da umidade relativa na cidade de Jales-SP, às $21 \mathrm{~h}$, no período referente ao mês de Janeiro e de Julho de 2010. Para que esse objetivo fosse alcançado se utilizou de adaptações das propostas metodológicas de Monteiro (1976), Mendonça (1994) e Amorim (2000). Foram realizados registros da temperatura e da umidade relativa por meio de mini estações em pontos fixos distribuídos pela malha urbana e pontos representativos do ambiente rural. Os resultados mostraram diferenças térmicas e higrométricas entre o rural e o urbano, além de diferenças entre os diversos bairros da cidade, que atingiram $10^{\circ} \mathrm{C}$.
\end{abstract}

PALAVRAS-CHAVE: Clima Urbano, Qualidade Ambiental e Planejamento, Jales.

URBAN CLIMATE IN JALES / SP: THERMAL ANALYSIS OF HYGROMETRIC FIELD FOR THE MONTHS OF JANUARY AND JULY 2010

Abstract: From the decade of 1960 on, changes in the labor relationship of countryside and urban area occurred, which had as consequences the rural exodus and the growth of Brazilian cities, and the City of Jales-SP is also in this context. Modifications in the natural characteristics caused by urbanization, marked by inadequate planning, resulted in several changes in the urban environment. Climate is one of the components of environment that is also subject to those changes. Therefore, this article aims to present the temperature and relative humidity in the City of Jales, at 9:00 P.M., from January through July 2010. In order to achieve this objective, adaptations of the methodological propositions of Monteiro (1976), Mendonça (1994) and Amorim (2000) were used. Records of temperature and relative humidity were logged using mini stations in fixed points distributed throughout the city and representative points of the rural environment. The results presented great thermal differences and hygrometric between the rural and the urban, besides the differences among the several neighborhoods of the city, which reached $10^{\circ} \mathrm{C}$.

KEY-WORDS: Urban Climate, Environmental Quality and Planning, Jales.

\section{INTRODUÇÃO}

No Brasil o crescimento das cidades teve como principal responsável o êxodo rural, que ocorreu não apenas pelo aumento das oportunidades de trabalho nas cidades, criadas pela industrialização e comércio, pelo maior acesso à educação e à saúde e pela possibilidade de uma vida melhor, mas principalmente pelas precárias condições de trabalho e vida no campo, fruto do:

[...] modelo agrícola, assim como do modelo econômico global que privilegia os grandes capitais, excluindo os pequenos. São os grandes proprietários que mais têm acesso ao crédito rural, às políticas de comercialização. A tecnologia moderna, por sua vez, é sofisticada, onerosa e não adequada à pequena escala de produção. (GRAZIANO NETO, 1985, p.58). 
As áreas urbanas que se caracterizam pela concentração de pessoas, ocupam, por sua vez, pequenas parcelas territoriais, mas são nelas que ocorre a maior degradação ambiental.
A estrutura agrária se transforma, expelindo para as cidades contingentes populacionais expressivos e pauperizados. Esta população urbana prolifera em cortiços nos grandes centros, nas favelas, nas periferias das cidades assentadas em terras públicas, em geral de difícil ocupação por problemas físicos (margens inundáveis, colinas e serras deslizáveis, mangues e litorais inabitáveis, etc.). Ao mesmo tempo, proliferam os grandes loteamentos para autoconstrução nas periferias deficientes em infraestrutura, originando formas específicas de viver que trazem uma nova problemática para a maioria dos países. (LOMBARDO, 1995, p.20).

Segundo Mota (1999, p. 17) "O aumento da população e a ampliação das cidades deveriam ser sempre acompanhadas do crescimento de toda a infraestrutura urbana, de modo a proporcionar aos habitantes uma mínima condição de vida". Ainda segundo o mesmo autor, "a ordenação deste crescimento faz-se necessária, de modo que as influências que o mesmo possa ter sobre o meio ambiente não se tornem prejudiciais aos habitantes". Entretanto, a realidade do processo de urbanização é bem diferente do ideal. Na maioria dos casos esse processo ocorre a partir de um planejamento inadequado, gerando assim um crescimento desordenado, acompanhado da falta da infraestrutura capaz de garantir a mínima qualidade ambiental.

De acordo com Branco e Rocha ${ }^{1}$ apud Mota (1999, p. 22) caminha-se para a utilização do planejamento urbano de forma integrada, em termos ecológicos, físico-territoriais, econômicos, sociais, administrativos, abrangendo as partes, os elementos e o todo de um sistema ou ecossistema. Essa concepção de planejamento está associada à idéia de desenvolvimento sustentável.

De acordo com o planejamento urbano integrado é necessário agir visando à preservação ambiental, pois é mais correto evitar os males gerados pela urbanização, ao invés de corrigi-los posteriormente. Com isso, entende-se a necessidade de considerar as questões ambientais na tomada de decisões relativas ao planejamento urbano.

O clima constitui-se numa das dimensões do ambiente urbano e seu estudo tem oferecido importantes contribuições ao equacionamento da questão ambiental das cidades. As condições climáticas destas áreas, entendidas como clima urbano, são derivadas da alteração da paisagem natural e da sua substituição por um ambiente construído, palco de intensas atividades humanas. (MENDONÇA, 2003, p. 93)

${ }^{1}$ BRANCO, S. M; ROCHA, A. A. Elementos da ciência do ambiente. 2. ed. São Paulo, CETESB/ASCETESB, 1987. 
As alterações das características naturais provocadas pela urbanização e, acentuadas pelo planejamento inadequado, provocam diversas modificações no ambiente urbano, sendo o clima um componente desse ambiente, ele está sujeito às influências dessas modificações.

As transformações na paisagem provocadas pelo surgimento e crescimento das cidades alteram o balanço de energia e o balanço hídrico urbano. Essas modificações são provocadas pela retirada da vegetação original, pelo aumento da circulação de veículos e pessoas, impermeabilização generalizada do solo, mudanças no relevo, concentração de edificações, canalização de córregos, além do lançamento de partículas e gases poluentes na atmosfera. (AMORIM, 2000, p.18)

Esses fatos geram mudanças no clima urbano e, como exemplos, são observados "problemas relacionados ao aumento da concentração de gases e partículas sólidas em suspensão e à intensificação do escoamento superficial com efeitos que comprometem a qualidade ambiental citadina". (BRANDÃO, 1996, p.10). Andrade (2005, p.75) completa a afirmação de Brandão dizendo que "O clima urbano deve assim ser considerado enquanto componente de qualidade do ambiente $e$, portanto, de contribuição para a qualidade de vida no meio urbano".

Entretanto, apesar dos esforços despendidos pelos climatólogos no sentido de apresentar subsídios ao planejamento das atividades humanas nas cidades, sua contribuição tem sido pequena e pouco valorizada pelas equipes de planejamento. O caráter marcadamente social e/ou econômico do planejamento tradicional e, o fortemente naturalista do planejamento ecológico, tem dificultado uma mais profícua participação de geógrafosclimatólogos em tais atividades (MONTEIRO, 1976).

Nesse sentido acredita-se que o estudo do clima urbano deve contar com instrumentos que o capacite no sentido de propor ações práticas e aplicáveis aos processos de planejamento.

Deste modo, o objetivo do presente artigo é apresentar a caracterização do clima urbano de Jales em relação aos meses de janeiro e julho de 2010, meses representativos do verão e do inverno, uma vez que o conhecimento das características do clima urbano é um fator fundamental para a realização de processos de planejamento ambientalmente adequados.

Para isso foi considerado o canal de percepção conforto térmico proposto por Monteiro (2003), que diz respeito ao subsistema termodinâmico. Segundo o mesmo autor, dentro do SCU - Sistema Clima Urbano - esse canal atravessa toda sua estrutura, uma vez que é insumo básico do sistema, todavia, sofre grandes transformações no meio urbano, o que altera de maneira inegável o balanço de energia líquida dentro do SCU. Segundo Monteiro (2003, p. 48)

"[...] a análise termodinâmica da cidade, fornece a informação básica ao arquiteto e ao urbanista. É exatamente nesse nível de criação dos espaços habitacionais e urbanos que se estabelecem os mecanismos de reciclagem e adaptação do sistema urbano 
ao clima em especial, e a qualidade do ambiente de modo mais abrangente."

\section{CARACTERIZAÇÃO DA ÁREA DE ESTUDOS}

Segundo Locatel (2000, p.15), a ocupação da região noroeste do Estado de São Paulo deu-se dentro da dinâmica ditada pelo complexo rural, com o estabelecimento das grandes posses. A figura 1 apresenta a Micro Região Geográfica de Jales, sendo a área do município foi destacada na cor amarela.

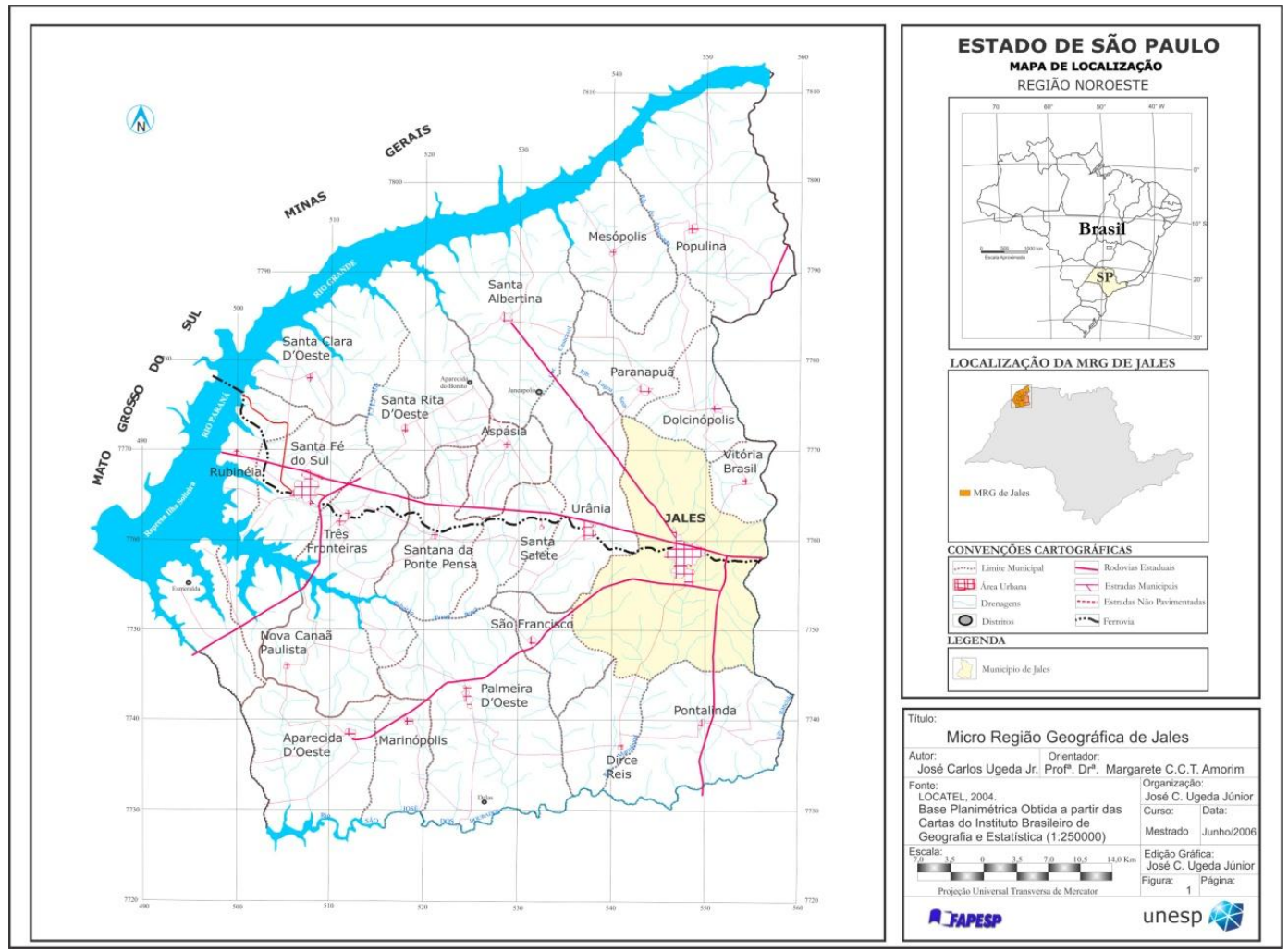

Figura 1: Mapa de Localização da Micro Região Geográfica de Jales.

Fonte: (UGEDA JUNIOR, 2007)

A partir desse processo de ocupação da região, foi fundada em 15 de abril de 1941 a Vila Jales e, em 24 de dezembro de 1948, foi elevada à categoria de município. A fundação de Jales se deu com o intuito de valorizar as terras ao redor para posterior parcelamento.

Apesar de a cidade ter sido implantada com o objetivo da especulação imobiliária, a sua concepção foi supostamente planejada, tanto no que diz respeito à área urbana como à área rural. O planejamento na área rural de Jales, segundo Monbeig (1984, p.236), ocorreu da seguinte forma, "[...] alguns loteadores chegaram a implantar um verdadeiro planejamento do espaço rural. Em Jales, o loteamento foi aberto em 1940 e o plano concebido sistematicamente, de maneira a oferecer propriedades cada vez maiores à medida que aumenta a distância do patrimônio". 
Para muitos autores o planejamento não ocorreu somente no campo, mas também na cidade, entretanto esse suposto planejamento teve como único objetivo a valorização das terras ao redor do patrimônio para seu parcelamento.

Segundo Nardoque:

Assim, a fundação do patrimônio precedeu a venda de lotes rurais e, para organizar a vila, foram destinados 40 alqueires. O engenheiro Euphly efetuou, para muitos, um suposto planejamento urbano, sendo que as quadras e os terrenos foram traçados levando-se em conta a circunvolução do Sol, de tal maneira que as casas construídas recebessem, sempre, em um dos lados, os raios solares e, de outro, sombra. Todas as ruas foram traçadas, inicialmente, para ter quatorze metros de largura, com leito carroçável de oito metros e duas grandes avenidas e praças demarcadas. [...]. O traçado ferroviário passou pelo plano original da cidade no sentido leste-oeste, dividindo-a ao meio. Portanto, qualquer estratégia de planejamento não permitiria que uma estrada de ferro dividisse a cidade ao meio. Esse fato não ocorreu em outras cidades fundadas ao longo da futura estrada de ferro, como Votuporanga, Fernandópolis, Urânia e Santa Fé do Sul. [...]. Também é fato que, em praticamente todas as cidades da MRG de Jales, os traçados urbanos originais se repetem, ou seja, duas avenidas que se cruzam no ponto central do plano, geralmente com a praça da igreja, além de ruas paralelas às avenidas. (NARDOQUE, 2007, p.329-330)

\section{O Mesmo autor ainda completa:}

Assim, a concepção de planejamento não existiu, pois o objetivo era fundar a cidade como estratégia para comercialização de terras e propagandear que o loteamento urbano seria servido pela ferrovia, afinal consistia, nas primeiras décadas do século $\mathrm{XX}$, como o mais eficiente meio de transporte, ainda mais para localidades longínquas como o extremo Noroeste paulista. Logo, a cidade serviu inicialmente, como suporte para a especulação imobiliária de terras rurais. (NARDOQUE, 2007, p.331)

Acerca do debate sobre a existência ou inexistência de um processo de planejamento urbano direcionado para a fundação de Jales, pode-se considerar que, dependendo da concepção de planejamento adotada é possível dizer que a cidade de Jales teve sua fundação planejada, pois como coloca Hasan Ozbekhan (1968) "planejar é agir sobre um objeto com o propósito de transformá-lo em uma situação que é mais desejável que a atual". Nesse sentido o fundador de Jales agiu de maneira planejada e sistemática, pois visando a valorização de suas terras, iniciou a transformação da área rural em urbana, entretanto, cabe destacar que, a finalidade desse planejamento foi exclusivamente econômica. 
Portanto à primeira análise, e com intencionalidade de valorização das terras, desejada no momento da fundação de Jales, houve o planejamento inicial, entretanto, questiona-se a finalidade e a adequabilidade de tal ação. Como o próprio Ozbekhan coloca, o planejamento adequado é aquele que traz mudanças de valores no intuito da construção de um futuro melhor, ou mais adequado. Souza (2002) corrobora essa afirmação dizendo que, o planejamento urbano é uma atividade que se remete ao futuro, pois busca prever a evolução dos processos, problemas e dificuldades gerados no momento atual. O planejamento visa ainda aproveitar as vantagens e benefícios que possivelmente surgirão.

Nesse sentido mais preciso da definição de planejamento, pode-se afirmar que o patrimônio de Jales não passou verdadeiramente por um processo de planejamento, ou que no mínimo esse planejamento teve caráter imediatista e exclusivamente econômico, não contemplando a mudança para o futuro, portanto, não se configurando em processo contínuo, como deveria ser. Sendo assim, admite-se que para a valorização econômica da região, seu fundador concebeu um plano inicial de ocupação das terras rurais e urbanas de Jales, inclusive como parte integrante do processo publicitário desse empreendimento, porém, essa iniciativa não se configura em processo de planejamento urbano adequado.

Pode-se afirmar então, que a cidade de Jales foi fundada a partir de uma intencionalidade de valorização econômica das terras rurais a partir do plano inicial de ocupação, ação que não acompanhou o crescimento da cidade, já que não há indícios de elaboração de processo continuo de planejamento, o que fez com que a cidade crescesse desordenadamente por mais de 50 anos. Apenas em meados da década de 1990 é que o Poder Público Municipal passou a realizar estudos para a elaboração do plano diretor, fato que aconteceu por obrigatoriedade legal. O crescimento urbano ocorrido sem planejamento adequado por mais de cinco décadas gerou problemas ambientais e sociais existentes até a atualidade, como pode ser observado em Ugeda Junior, 2007.

\section{MATERIAIS E MÉTODO}

Para o desenvolvimento do presente artigo foram utilizados os seguintes materiais: Material bibliográfico e cartográfico: disponível na biblioteca da FCT/Unesp e em outros acervos.

Para os levantamentos de dados meteorológicos em campo, foram utilizados equipamentos automáticos, treze Mini-Estações Meteorológicas DATA LOGGER/CLIMA LOGGER sem fio de $433 \mathrm{MHz}$, anemômetro digital da marca Incoterm, além de duas estações meteorológicas automáticas do tipo "Vantage PRO 2" da marca "Davis Instruments". Os registros de temperatura analisados neste artigo, dizem respeito às $21 \mathrm{~h}$ para os meses de janeiro e julho de 2010.

Também foram utilizadas as cartas sinóticas de superfície disponibilizadas pelo site da Marinha do Brasil $^{2}$, além da utilização de imagens de satélites Goes, disponibilizadas pelo CPTEC/INPE ${ }^{3}$.

\footnotetext{
${ }^{2}$ www.mar.mil.br
}

${ }^{3}$ www.cptec.inpe.br 
Para o desenvolvimento deste artigo, o método utilizado está vinculado ao proposto por Monteiro em 1976, denominado Sistema Clima Urbano, que por sua vez foi construído a partir da Teoria Geral dos Sistemas, que segundo o mesmo autor (2003, p.16) traz a "possibilidade alternativa de usar tanto o método indutivo quando o dedutivo".

\section{CARACTERÍSTICAS DA TEMPERATURA E DA UMIDADE DO AR EM JALES/SP}

O clima urbano é entendido como um sistema, ou seja, a expressão das condições atmosféricas, resultantes da interação de diferentes escalas climáticas e de superfície. (MONTEIRO, 1976). Esta integração é responsável por variações que podem acarretar problemas econômicos e sociais. O sistema climático é constituído por uma série de subsistemas integrados, organizado e hierarquizado horizontalmente (na estrutura) e verticalmente (na função). Em perspectiva integrada, no estudo do clima urbano está incluída à análise espacial, ambiental e regional, a fim de dar subsídios ao ordenamento territorial urbano (AMORIM, 2000, p.37).

Portanto, para se apresentar os resultados faz-se necessário a caracterização do mês de janeiro de 2010. Segundo a Síntese Sinótica Mensal para esse mês, publicada pelo CEPTEC/INPE em 10 de fevereiro de 2010, em relação aos sistemas frontais, houve pouca ocorrência, sendo que apenas três chegaram a aturar no continente Brasileiro. Entretanto, após a passagem de uma frente pelo litoral no dia 14, houve a formação de uma Zona de Convergência de Umidade (ZCOU), o que intensificou as chuvas no estado de São Paulo a partir desta data. Este sistema mantevese atuante até o dia 15, quando um Vórtice Ciclônico de Altos Níveis (VCAN), trouxe mais chuvas para o sul do Brasil e partes do Estado de São Paulo. O mês de janeiro, que já havia começado chuvoso, teve as chuvas intensificadas por conta desse aporte de umidade.

Outra ZCOU se formou entre o sul amazônico, parte do Centro-Oeste, principalmente entre Mato Grosso, Goiás, São Paulo, sul de Minas Gerais e Rio de Janeiro, áreas onde intensas precipitações foram registradas. Esta ZCOU durou até o dia 23. No final do mês, mais uma VCAN atuou entre os dias 24 e 29 sobre parte da Região Sul, estendendo-se até São Paulo e Rio de Janeiro, o que favoreceu a ocorrência de mais chuva nestas áreas. As chuvas mais intensas ficaram concentradas em São Paulo e na Baixada Fluminense (entre os dias 24 e 26).

$\mathrm{Na}$ Figura 2, Gráfico de Análise Rítmica é possível observar a predominância de ocorrência da Massa Tropical Atlântica (mTa), dos cavados e da ZCOU, além da expressiva precipitação registrada nesse período na cidade de Jales. 


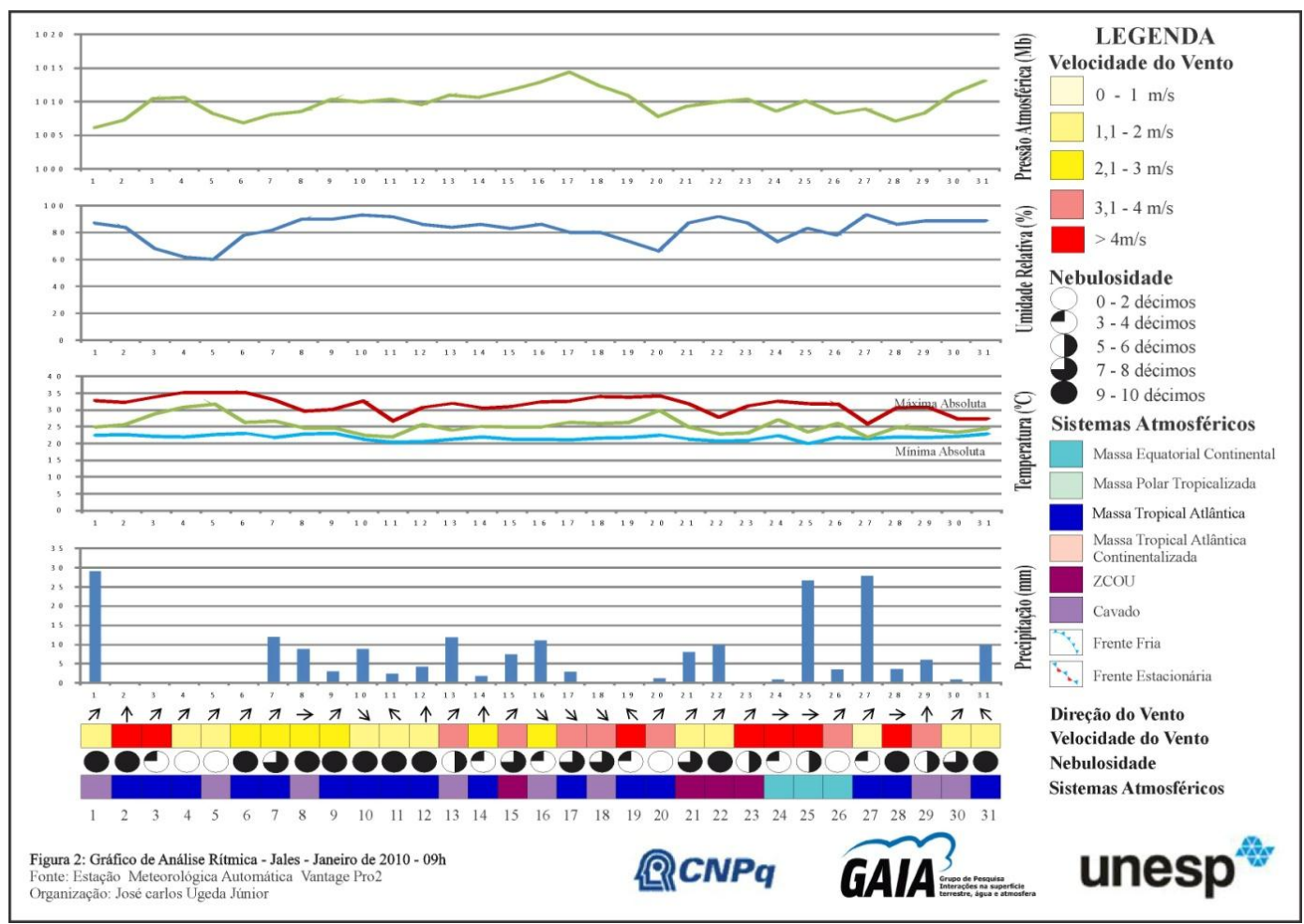

Figura 2: Gráfico de Análise Rítmica - Jales - Janeiro de 2010 - 09h.

Segundo o CEPEC houve também anomalias positivas significativas de precipitação sobre grande parte do centro-sul do Brasil, principalmente nos estados do Rio Grande do Sul, Santa Catarina, Paraná, São Paulo e Mato Grosso do Sul. Em algumas localidades desses estados os volumes de chuva duplicaram os valores climatológicos normais, especialmente no centro-sul do estado de São Paulo.

Associado a esses sistemas houve também a ocorrência anômala do vento de quadrante norte, que fez direcionar o Jato de Baixos Níveis (JBN) para parte do Sudeste e Sul do Brasil, fazendo que o ar quente e úmido da região tropical contribuísse para intensificar as chuvas sobre o Estado de São Paulo.

As chuvas e os ventos em Jales no mês de janeiro seguiram o padrão do Estado de São Paulo, sendo que os ventos fortes e o excesso de chuva fizeram com que as diferenças térmicas entre a área urbana e rural, além das intraurbanas fossem amenizadas. Entretanto, apesar dessa configuração do tempo para o mês de janeiro, em alguns dias foram observadas diferenças superiores à $10^{\circ} \mathrm{C}$, Para as $21 \mathrm{~h}$ a maior diferença ocorreu no dia 4 de janeiro atingindo $7,4^{\circ} \mathrm{C}$. A diferença mínima para as $21 \mathrm{~h}$ foi observada no dia 02 de janeiro, ficando em $1,2^{\circ} \mathrm{C}$.

A seguir serão apresentadas as cartas de temperatura do ar e de umidade relativa para os dias mais representativos do mês de janeiro às $21 \mathrm{~h}$, uma vez que neste horário as diferenças entre o rural e o urbano se acentuam, demonstrando a capacidade diferenciada de ganhos e perdas de calor entre estes ambientes. 
No dia primeiro observou-se a formação de três bolsões de ar quente (Figura 3) com temperaturas entre $24,2,24,6$, e $24,8^{\circ} \mathrm{C}$. O primeiro deles a leste, o segundo ao sul e o terceiro ao oeste. Já o centro, principalmente em sua porção norte, apresentava as temperaturas mais amenas, 22,6 e $22,8^{\circ} \mathrm{C}$. Esse padrão se repetiu em dias de temperatura mais baixa, geralmente relacionado à instabilidade atmosférica, como é o caso do dia 5 (Figura 14). Essas condições fizeram com que as diferenças térmicas entre os pontos fossem reduzidas.

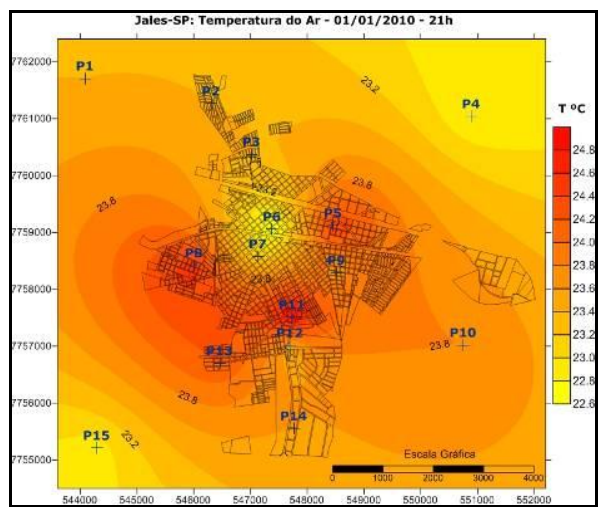

Figura 3: Temperatura do $\operatorname{Ar} 1 / 1 / 2010,21 \mathrm{~h}$.

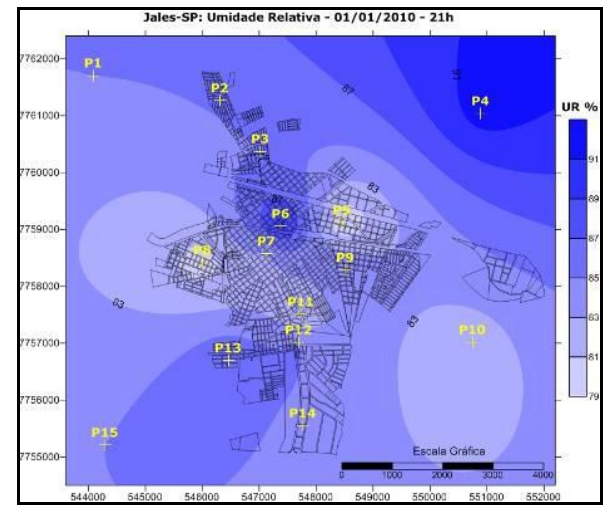

Figura 4: Umidade Relativa 1/1/2010, $21 \mathrm{~h}$.

Já nos dias 2, 3 e 4 apresentados nas Figuras 5, 7 e 11, as temperaturas, assim como as diferenças térmicas e higrométricas entre os pontos foram maiores. A área de maior temperatura foi a área centro sul do mapa, com temperatura de $32^{\circ} \mathrm{C}$, com destaque também ao conjunto habitacional Arapuã, ao norte, com temperatura de $30^{\circ} \mathrm{C}$, em detrimento dos bairros localizados na periferia da cidade.

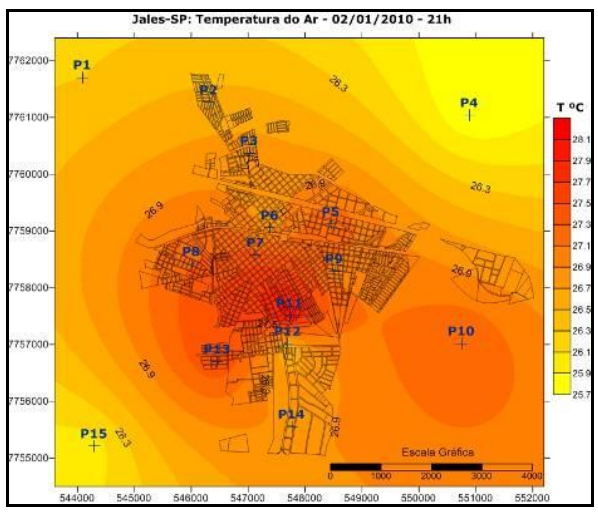

Figura 5: Temperatura do $\operatorname{Ar} 2 / 1 / 2010,21 \mathrm{~h}$.

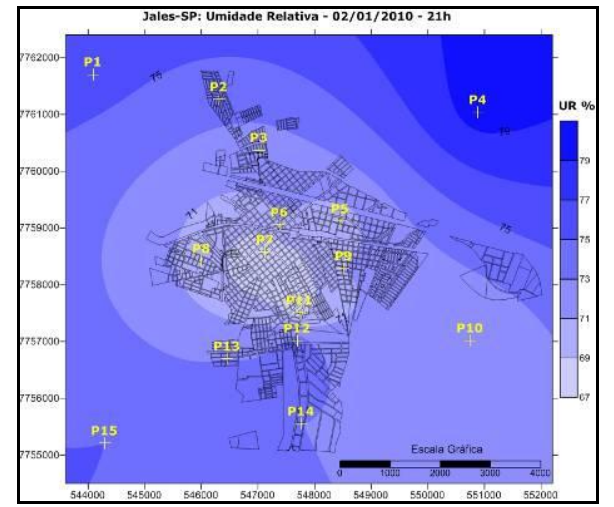

Figura 6: Umidade Relativa 2/1/2010, $21 \mathrm{~h}$. 


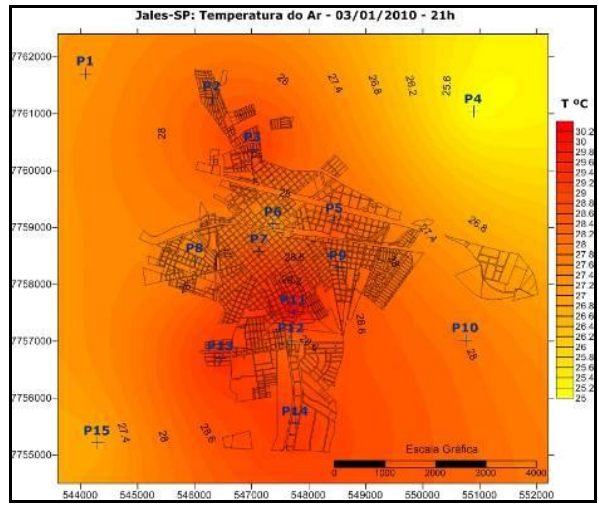

Figura 7: Temperatura do $\operatorname{Ar} 3 / 1 / 2010,21 \mathrm{~h}$.

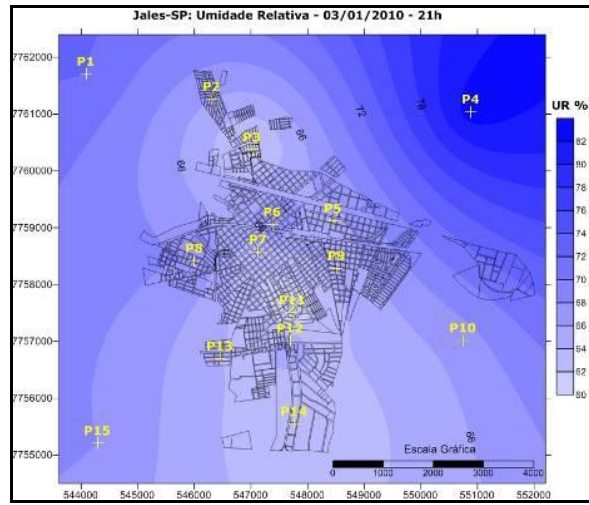

Figura 8: Umidade Relativa 3/1/2010, 21h.

Tanto a área ao sul, nas proximidades do ponto 11 , quanto a área ao norte, nas proximidades do ponto 3 , são áreas densamente ocupadas. No ponto 3, por um conjunto habitacional, com lotes pequenos e construções que ocupam quase a totalidade do lote, além de significativa ocorrência de telhados do tipo fibrocimento, como pode ser observado na Figura 9. Já o ponto 11 se localiza em bairro residencial também densamente ocupado (Figura 10)

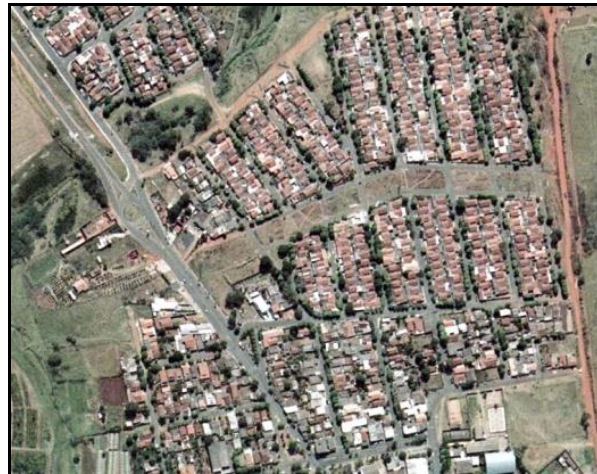

Figura 9: Proximidades do Ponto 3.

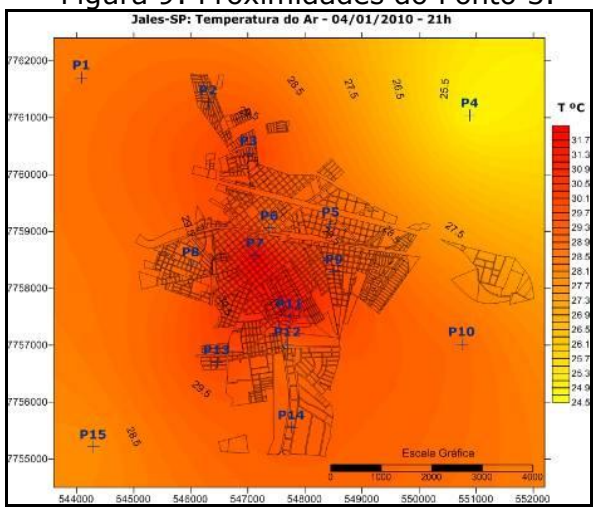

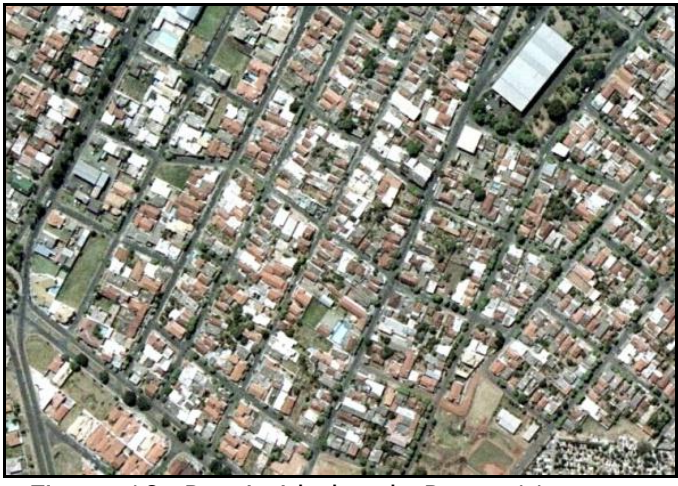

Figura 10: Proximidades do Ponto 11.

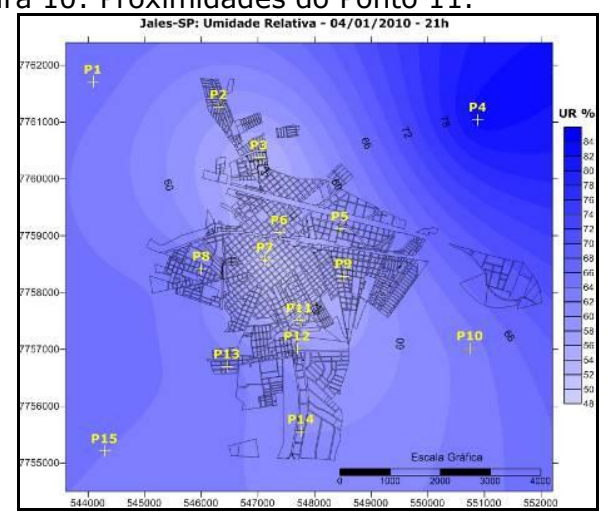

Figura 11: Temperatura do $\operatorname{Ar} 4 / 1 / 2010,21 \mathrm{~h}$. Figura 12: Umidade Relativa 4/1/2010, $21 \mathrm{~h}$.

No dia 4, (Figura 11) nota-se que a região mais aquecida está localizada entre os pontos 7 ao 11 . Essa área se caracteriza por uma mistura de usos comerciais e de serviços (P7) além de residencial (P11). De maneira geral 
esses bairros apresentam alta densidade de ocupação e baixa taxa de vegetação urbana, como pode ser observado na Figura 13.

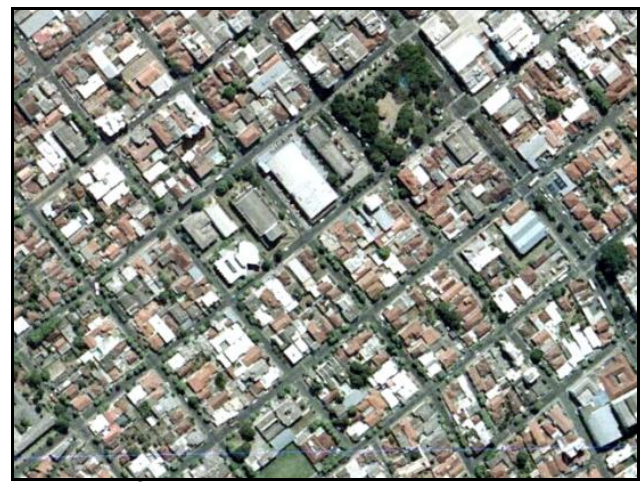

Figura 13: Área localizada entre os pontos 7 e 11.

$\mathrm{Na}$ comparação entre a cidade e o campo as temperaturas mais baixas foram registradas no campo, destacando-se as regiões nordeste e sudoeste do mapa onde se tem respectivamente, $22,8^{\circ} \mathrm{C}$ e $22,6^{\circ} \mathrm{C}$ para o dia primeiro, $25,6^{\circ} \mathrm{C}$ e $26^{\circ} \mathrm{C}$ para o dia dois, $25^{\circ} \mathrm{C}$ e $26,8^{\circ} \mathrm{C}$ para o dia três, $24,5^{\circ} \mathrm{C}$ e $27,9^{\circ} \mathrm{C}$ para o dia quatro, $26^{\circ} \mathrm{C}$ e $26,4^{\circ} \mathrm{C}$ para o dia cinco e $23,8^{\circ} \mathrm{C}$ e $24,6^{\circ} \mathrm{C}$ para o dia seis. Destaca-se também a zona rural a noroeste do mapa (Figura 11), sendo que essa região apresenta as temperaturas mais altas do ambiente rural. A temperatura mais elevada nessa área pode ser explicada pelo fato da direção predominante do vento no mês de janeiro ter sido sudeste, de modo que o vento ao atravessar a cidade se aquece, levando esse calor adquirido para a zona rural a noroeste.

O padrão descrito acima está relacionado com menor instabilidade atmosférica, sendo que no dia primeiro a atmosfera estava instável em função da atuação de um sistema de baixa pressão atmosférica, com alta nebulosidade, chuva e ventos fortes. Entre os dias dois a quatro a atmosfera apresentou maior estabilidade com diminuição da nebulosidade, ventos mais fracos e sem chuva. A partir do dia 5 a atmosfera voltou a ficar instável, com aumento da nebulosidade, da velocidade do vento e da chuva. Essa descrição pode ser observada da Figura 2 - Gráfico de análise rítmica e na Figura 16. Organização das imagens do satélite Goes.

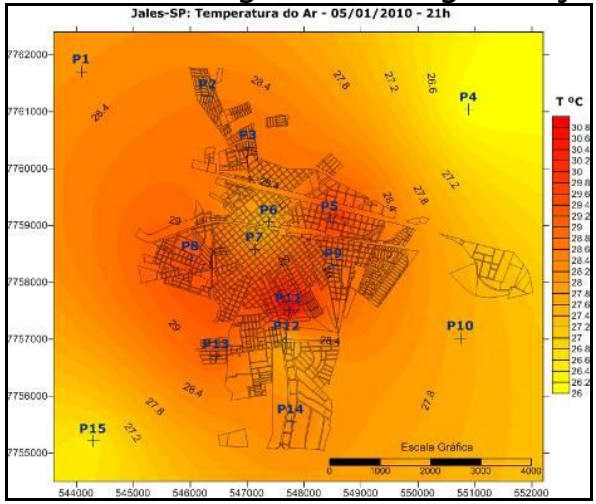

Figura 14: Temperatura do Ar 5/1/2010,21h

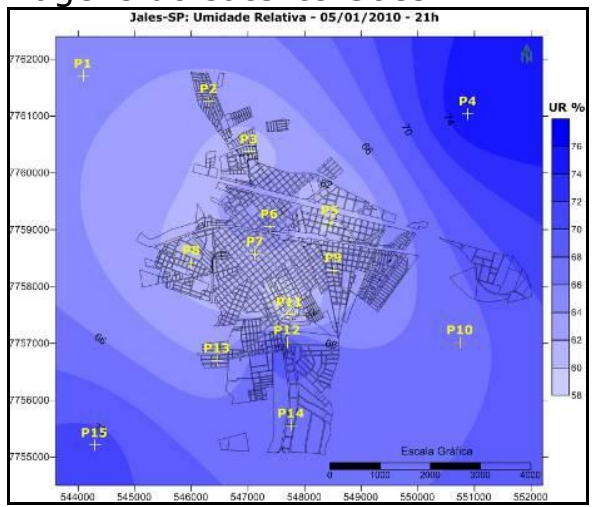

Figura 15: Umidade Relativa 5/1/2010, $21 \mathrm{~h}$. 


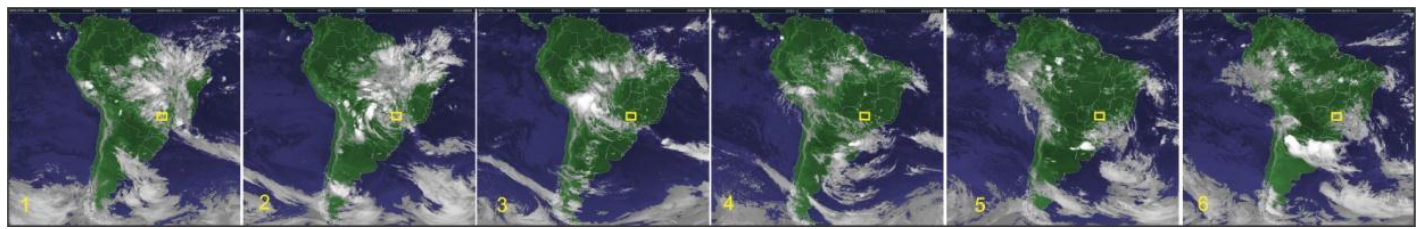

Figura 16: Organização das Imagens Goes do dia $1^{0}$ ao dia 6 de janeiro de 2010.

A partir das figuras $17,18,19$, que apresentam as temperaturas do ar para os dias dezoito, dezenove e vinte de janeiro, às $21 \mathrm{~h}$, pode-se identificar o padrão de aquecimento dos dias com atmosfera instável, sendo que destaca-se a área centro-leste do mapa, registrando temperatura de até $28,2^{\circ} \mathrm{C}$ no dia dezoito. Esta área que também se caracteriza como de transição entre o centro da cidade e os bairros, sendo no centro de uso predominantemente residencial e com lotes maiores enquanto que nos bairros os lotes são menores, havendo maior ocorrência de telhados do tipo fibrocimento. Toda essa região é densamente construída, com poucos espaços livres de construção. A vegetação urbana tem maior incidência nos bairros próximos, e é menos significativa no centro.

$\mathrm{Na}$ comparação entre o campo e a cidade, novamente se destacam as áreas nordeste e sudoeste do mapa (Figuras 17, 18 e 19), que apresentam temperaturas inferiores à $23,5^{\circ} \mathrm{C}$. Entretanto, destaca-se que, no dia vinte a menor temperatura foi registrada no centro da cidade $\left(22,6^{\circ} \mathrm{C}\right)$. Esse fato pode ser explicado devido à ocorrência de chuva e vento moderado a partir das 20 horas, o que pode desorganizar o padrão térmico identificado em diversos outros episódios.
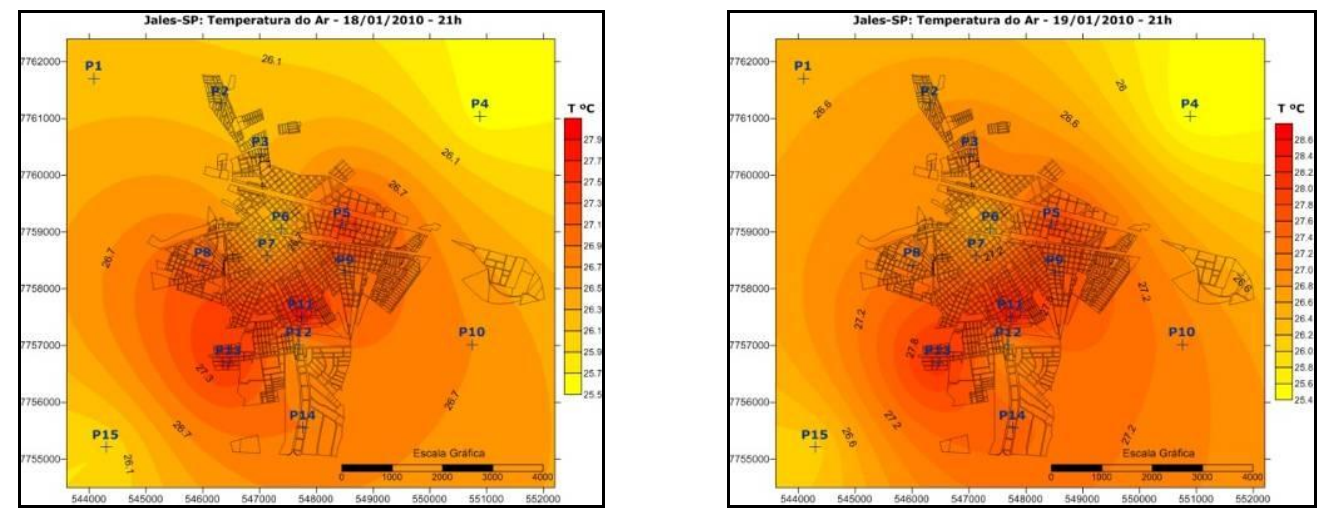

Figura17: Temperatura do $\operatorname{Ar} 18 / 1 / 2010,21 \mathrm{~h}$. Figura18: Temperatura do $\operatorname{Ar} 19 / 1 / 2010,21 \mathrm{~h}$. 

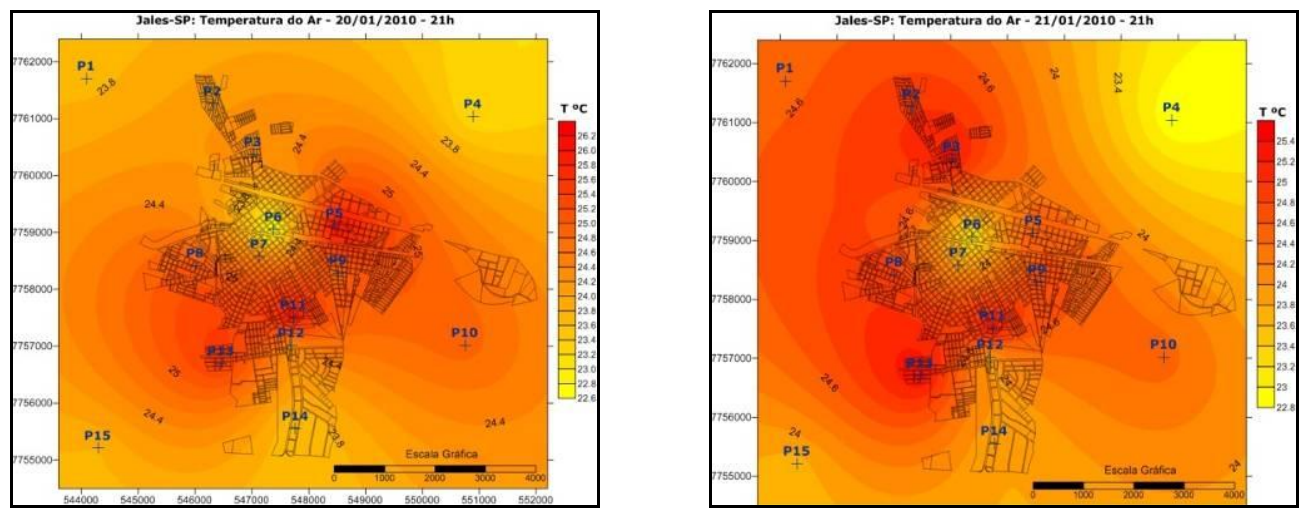

Figura19: Temperatura do $\operatorname{Ar} 20 / 1 / 2010,21 \mathrm{~h}$. Figura20: Temperatura do Ar 21/1/2010, $21 \mathrm{~h}$.

A figura 20 apresenta a temperatura do ar para o dia 21 de janeiro às $21 \mathrm{~h}$, destacando certa repetição do padrão já apresentado, com temperaturas e diferenças térmicas entre os pontos, mais baixas. Nesta figura observa-se que as áreas a leste a sul e a oeste apresentam temperaturas mais elevadas $(26,7 \mathrm{C})$, sendo que elas agora se encontram ligadas por um bolsão de temperatura mais elevada, que se estende também a nordeste da cidade.

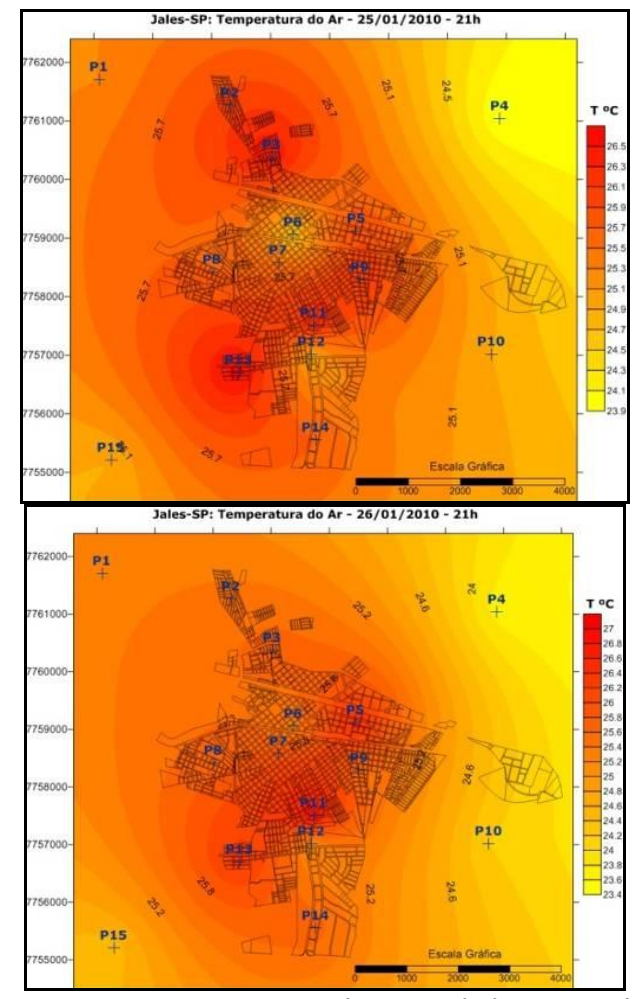

Figura22: Temperatura do $\operatorname{Ar} 25 / 1 / 2010,21 \mathrm{~h}$.

Figura23: Temperatura do $\operatorname{Ar} 26 / 1 / 2010,21 \mathrm{~h}$.

Por fim, mais duas áreas merecem destaque. As áreas dos conjuntos habitacionais JACB e Arapuã, (P2 e P3) que podem ser identificas na Figura 22 , foram às áreas ao norte onde se observou temperaturas superiores a 
$26^{\circ} \mathrm{C}$. Além da área a sudoeste da cidade (P13) que apresentou temperatura de $23,8^{\circ} \mathrm{C}$. Essas áreas são conjuntos habitacionais, compostos por lotes pequenos e densamente ocupados. As casas têm cobertura de telha de barro, entretanto, é possível observar muitas extensões nas construções como garagens e dispensas, os populares "puxadinhos", com cobertura do tipo fibrocimento. Embora nesses bairros exista quantidade significativa de espaços livres de construção, estes são basicamente áreas de segurança para as linhas de transmissão de energia, e não possuem vegetação do tipo arbóreo, apenas com vegetação rasteira. Em linhas gerais esses foram os principais padrões observados no mês de janeiro de 2010, assim como suas principais causas. A seguir serão apresentados os dados relativos ao mês de Julho de 2010.

A caracterização dos principais sistemas atmosféricos atuantes no mês de julho de 2010 foi feita através dos dados registrados na estação automática localizada no ambiente rural além dos dados disponibilizados pelo CEPTEC/INPE, das cartas sinóticas disponibilizadas pela Marinha do Brasil, e das imagens do satélite Goes.

O mês de Julho apresenta 14 milímetros de chuva como média climatológica, entretanto, no mês de julho de 2010 foi registrado apenas 0,8 milímetros de chuva na área rural e 0,0 milímetros na área urbana. Os dados do CPTEC também apresentaram que a região de Jales teve em média um déficit de 25 milímetros de chuva para este mês, e a umidade relativa atingiu níveis críticos. A precipitação baixa é explicada pela intensa atuação da massa tropical atlântica continentalizada (mTac) quente e seca fazendo um bloqueio impedindo que as frentes frias atingissem o interior do continente. Esse sistema perdurou até o dia 12 com pequena variação de umidade relativa e nebulosidade, que se mantiveram sempre baixas. Também foi observada a atuação da massa polar atlântica (mPa) e da massa polar envelhecida ( $\mathrm{mPv}$ )

Em relação aos sistemas frontais, foram observados nove sistemas que atuaram na América do Sul, sendo que oito deles atingiram o território brasileiro e um se desviou para o oceano. Os três primeiros foram observados nos dias 4, 7 e 10 respectivamente, não ultrapassando o estado de Santa Catarina devido ao bloqueio citado acima. No dia 10 às 03h observou-se a presença de um cavado sobre a área de estudo que resultou no aumento da nebulosidade e ligeiro aumento da umidade relativa. No dia 11 às $15 \mathrm{~h}$ notou-se outro cavado atuando sobre a região de Jales. A Figura 24 Gráfico de Análise Rítmica apresenta pode se identificar os principais sistemas atuantes para o mês de julho. 


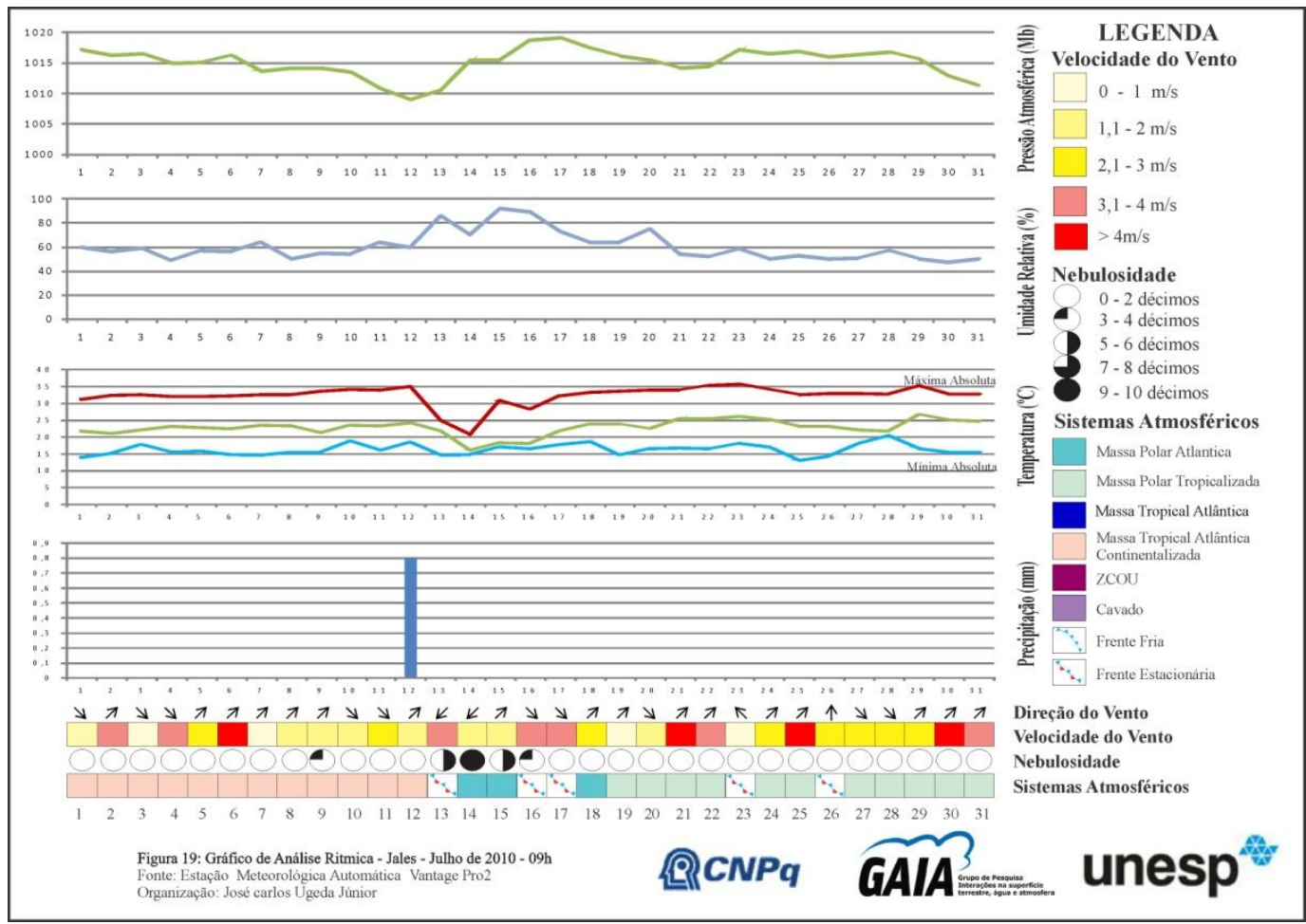

Figura 24: Gráfico de Análise Rítmica - Jales - Julho de 2010 - 09h.

O quarto sistema frontal atuou sobre o interior paulista apenas a partir do dia 12 às $21 \mathrm{~h}$, sendo que a umidade e a nebulosidade começaram a aumentar devido a passagem da frente fria que impulsionada pelo jato polar sul (JPS) conseguiu romper a barreira criada pela mTac. No dia 13 às $9 \mathrm{~h}$ a frente fria estava localizada sobre a área de estudo, e permaneceu estacionária nesse ponto até o dia 14 às $9 \mathrm{~h}$ quando começou a se deslocar lentamente para o norte. O único episódio de precipitação registrado nesse mês aconteceu exatamente devido a passagem desse sistema frontal, porém, a precipitação de 0,8 milímetros foi registrada apenas na zona rural no dia 12 às $22 \mathrm{~h}$.

A partir do dia 19 o quinto sistema frontal alcançou o interior paulista, permanecendo até o dia 20 quando se desviou para o oceano. No dia 21 um cavado atuou sobre a área.

O último sistema frontal observado em julho alcançou a região de Jales no dia 26 às 9h, causando aumento da umidade relativa, entretanto, com baixa nebulosidade e sem chuva. Esse sistema permaneceu na região até o dia 27 com pequeno deslocamento no sentido norte-sul.

A partir do dia 18 notou-se a atuação da $\mathrm{mPa}$ que passando pelo aquecimento basal tornou-se mPv e perdurou até o dia 31 .

A seguir serão apresentadas as cartas de temperatura do ar e umidade relativa para os dias mais representativos do mês às $21 \mathrm{~h}$.

Os maiores valores de diferenças tanto térmicas como higrométricas foram observados às $21 \mathrm{~h}$ do mês de julho, principalmente em função da estabilidade atmosférica. Como a situação sinótica já foi colocada anteriormente, passar-se-á aos valores. Em relação à diferença térmica, 
foram identificados 31 dias com diferença superior a $2^{\circ} \mathrm{C}$, sendo que a diferença mínima foi de $2,2^{\circ} \mathrm{C}$ no dia 16 e a máxima foi de $8,5^{\circ} \mathrm{C}$ no dia 25 , o que é muito significativo para o tamanho da cidade estudada.

Em relação à diferença higrométrica, também foi às $21 \mathrm{~h}$ que surgiram os maiores valores, sendo que a diferença mínima observada foi de $9 \%$ no dia 17 e a máxima de $39 \%$ no dia primeiro. Ressalta-se que associado a alta estabilidade atmosférica observada no mês de julho, às $21 \mathrm{~h}$ também foram observados os mais baixos valores de velocidade do vento, fatores que criaram as condições ideais para o surgimento das ilhas de calor. Nesse horário também não foi registrado nenhuma precipitação, mesmo quando houve atuação dos sistemas frontais.

Através da Figura 27, nota-se que no dia primeiro a zona rural se apresentou menos aquecida do que área urbana, com destaque especial para o ponto 4 que apresentou a menor temperatura, $19,0^{\circ} \mathrm{C}$. Já nas áreas intraurbanas percebeu-se a formação de duas ilhas de calor, a primeira no ponto $2 \mathrm{com} 25,5^{\circ} \mathrm{C}$ e a segunda no ponto 7 estendendo-se até ao ponto 11 , com $25,7^{\circ} \mathrm{C}$. Nesse dia não se observou a formação de ilhas frescas dentro da área urbana, apenas uma área relativamente menos aquecida localizada entre os pontos 5 e 6 . A diferença térmica foi de $8,8^{\circ} \mathrm{C}$, sendo que a temperatura variou entre 15,5 e $24,3^{\circ} \mathrm{C}$.

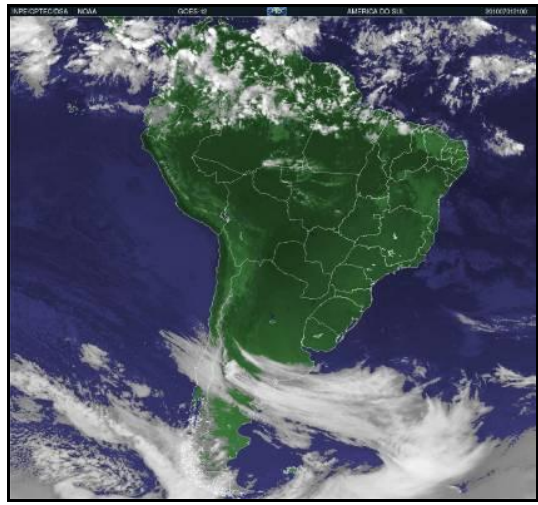

Figura 25: Imagem Goes 01/07/2010, 21h

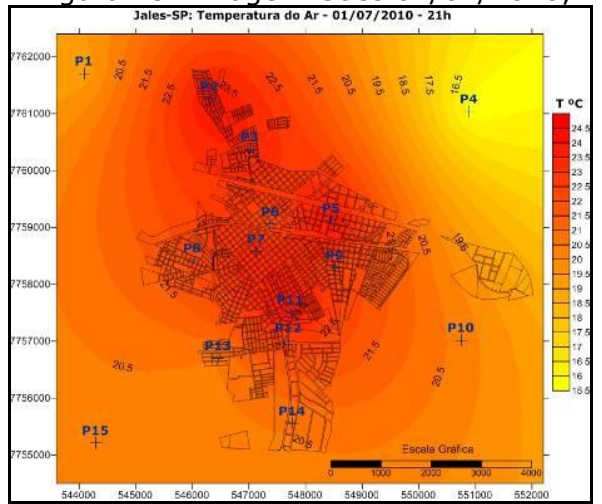

Figura 27: Temperatura do Ar 01/07/2010, $21 \mathrm{~h}$.

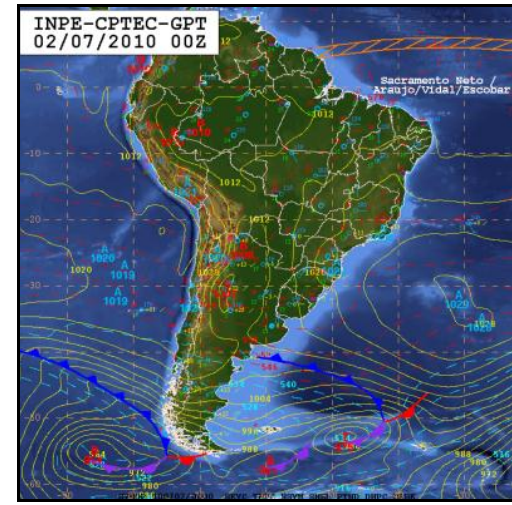

Figura 26: Carta Sinótica 01/07/2010, 21h

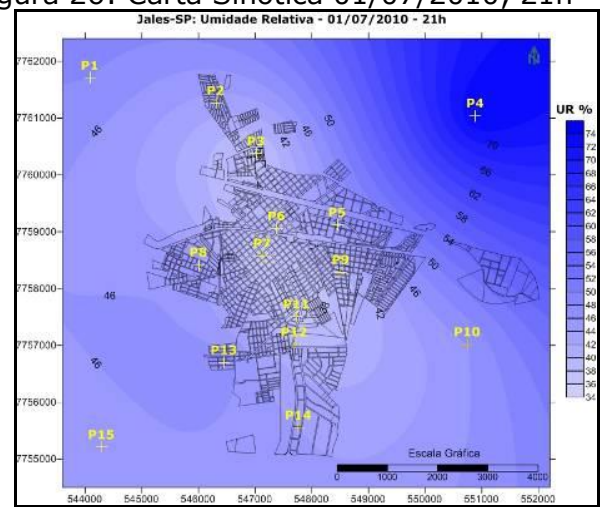

Figura 28: Umidade Relativa 01/07/2010,

A umidade relativa seguiu o padrão centro-periferia (Figura28), já que a zona rural se apresentou mais úmida, com destaque especial para o ponto 
4 com $74 \%$ de umidade. Nas áreas intraurbanas observou-se uma ilha seca que atravessou a cidade se estendendo do ponto 2 até ao ponto 12 , com $34 \%$ de unidade. A diferença higrométrica foi de $39 \%$ sendo que a umidade relativa variou entre 34 a $73 \%$.

Destaca-se que o padrão observado no dia primeiro foi reconhecido na bibliografia em outros estudos, entretanto, deve-se enfatizar uma característica importante: a máxima expressão das ilhas de calor ocorreu em áreas residenciais ou densamente ocupadas ou com baixa vegetação como é o caso dos pontos 2, 3, 5 e 9, além é claro do centro comercial (P7). Já no ponto 6 (centro residencial com lotes grandes e arborização significativa, com casas mais antigas predominantemente com cobertura de telha de barro) notou-se o resfriamento do ar, ainda que com baixa intensidade, mas com capacidade de formação de uma ilha fresca. A zona rural permaneceu menos aquecida do que as áreas urbanas.

No dia 2 (Figura 29) a situação sinótica não se alterou, sendo possível observar que a diferença térmica caiu para $3,7^{\circ} \mathrm{C}$ porque a temperatura mínima se elevou $5^{\circ} \mathrm{C}$. A região nordeste da zona rural (P4) se encontrava aquecida, com $23,6^{\circ} \mathrm{C}$, entretanto, todo o restante da área rural apresentou temperatura inferior às áreas urbanas. Dentro do perímetro urbano foi possível observar a formação de duas ilhas de calor, a primeira no ponto $2 \mathrm{com} 22,8^{\circ} \mathrm{C}$, e a segunda no ponto $11 \mathrm{com} 23,8^{\circ} \mathrm{C}$. O ponto 9, assim como o centro da cidade (P6 e P7) se apresentaram menos aquecidos, porém com baixa diferença térmica. A alteração para o dia primeiro foi exatamente a formação de uma ilha fresca no centro da cidade, especialmente no ponto 6.

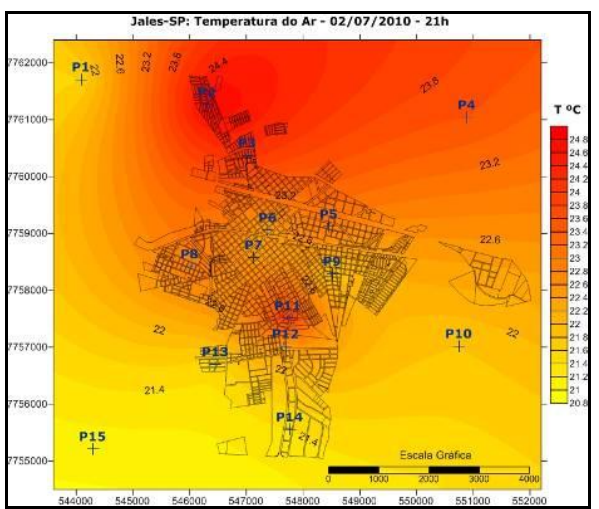

Figura 29: Temperatura do Ar 02/07/2010, 21h.

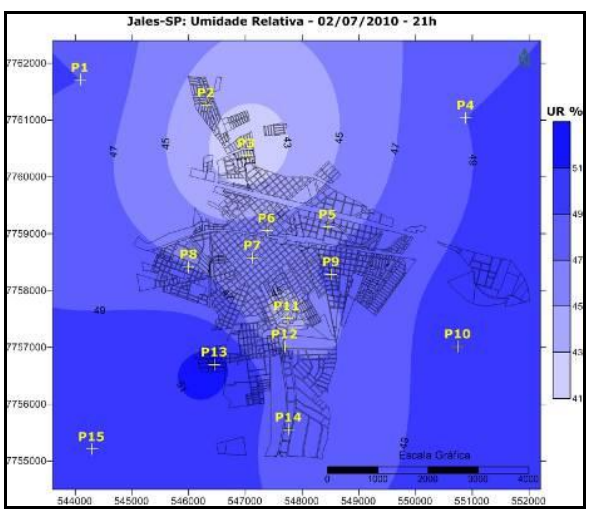

Figura 30: Umidade Relativa 02/07/2010

A umidade relativa (Figura 30) seguiu o mesmo padrão do dia anterior, com zona rural mais úmida, $52 \%$, com a formação de uma ilha úmida no ponto 13 , também com $52 \%$ de umidade. Percebeu-se a formação de uma ilha seca no ponto 3 , com $41 \%$ de umidade, que se estendeu para o centro da cidade com $45 \%$ de umidade. A diferença higrométrica foi de $11 \% \mathrm{com}$ umidade variando entre 41 e $52 \%$.

No dia 3 (Figura 31) notou-se a repetição do padrão observado no dia 2, principalmente devido à situação sinótica que permaneceu sem alteração. 
A diferença térmica ficou em $4,6^{\circ} \mathrm{C}$, com temperatura variando entre 21,2 e $25,8^{\circ} \mathrm{C}$.

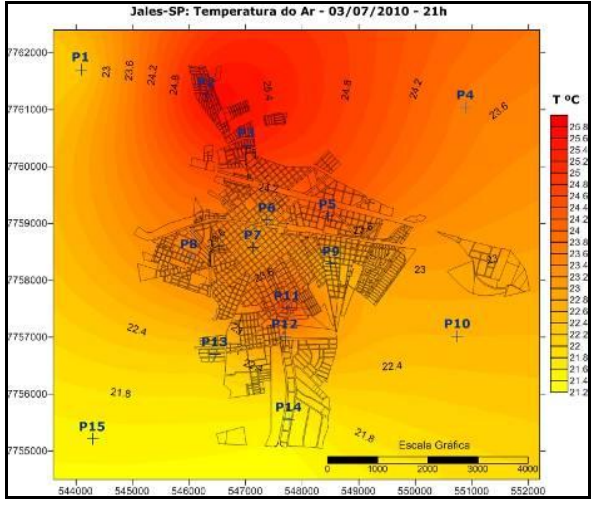

Figura 31: Temperatura do Ar 03/07/2010, 21h.

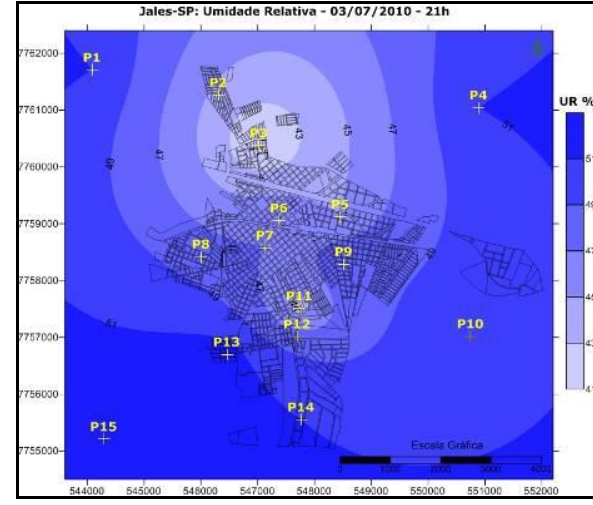

Figura 32: Umidade Relativa 03/07/2010

A umidade relativa (Figura 32) seguiu o mesmo padrão, sendo: zona rural mais úmida, zona urbana mais seca, com formação de uma ilha seca no ponto 3 que se estendeu até ao ponto $12 \mathrm{com}$ menor intensidade.

No dia 4 (Figura 33) a situação sinótica continuou inalterada, sendo que a diferença térmica se ampliou para $7,5^{\circ} \mathrm{C}$ com temperatura variando entre 18,0 e $25,5^{\circ} \mathrm{C}$. A diferença higrométrica também se ampliou para $35 \%$, variando entre 36 e $71 \%$. (Figura 34)

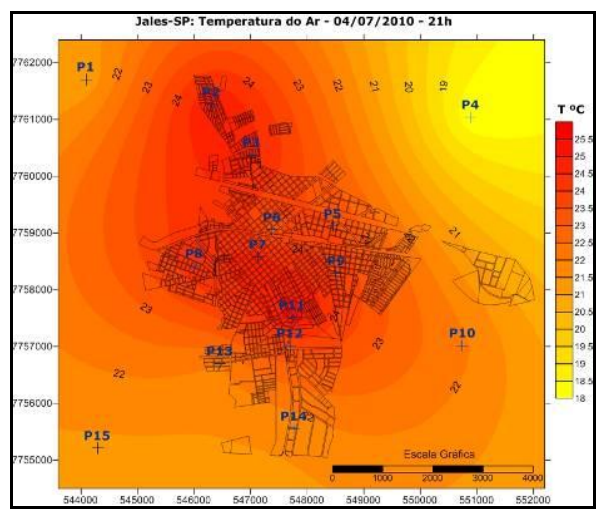

Figura 33: Temperatura do Ar 04/07/2010, $21 \mathrm{~h}$.

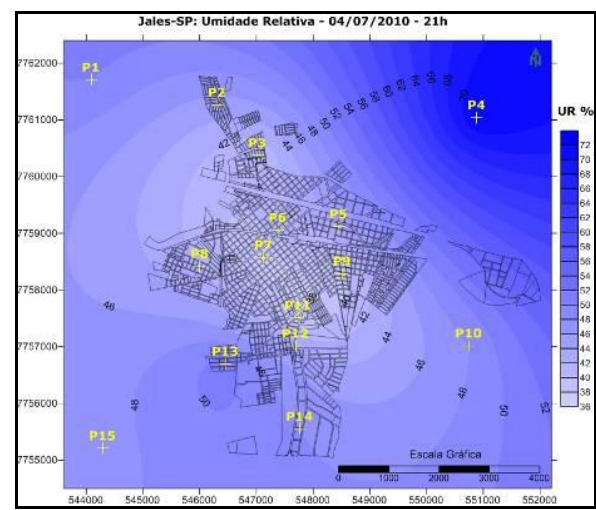

Figura 34: Umidade Relativa 04/07/2010

Entre os dias 5 a 11 esse padrão se repetiu, com pequenas variações de magnitude, sendo que a principal delas ocorreu no dia 9 quando o centro (P6 e P7) apresentavam-se menos aquecidos.

Em linhas gerais, esse padrão foi observado quando ocorreu alta diferença térmica e pode ser assim caracterizado: a zona rural se encontrou menos aquecida do que a urbana, com destaque para o ponto 4, que teve a menor temperatura registrada. Na área urbana notou-se a formação de duas ilhas de calor, uma entre os pontos 2 e 3, e outra entre os pontos 7 e 12 . O padrão observado teve pouca variação nesse período, sendo que apenas os dias 8 e 10 merecem destaque por não apresentarem a formação da ilha de calor no ponto 7, sendo que ela ficou restrita ao ponto 11, como se 
observa nas Figuras 35A, 35B e 35C. Destaca-se também o dia 9, que apresentou a formação de ilha fresca no ponto 6 .

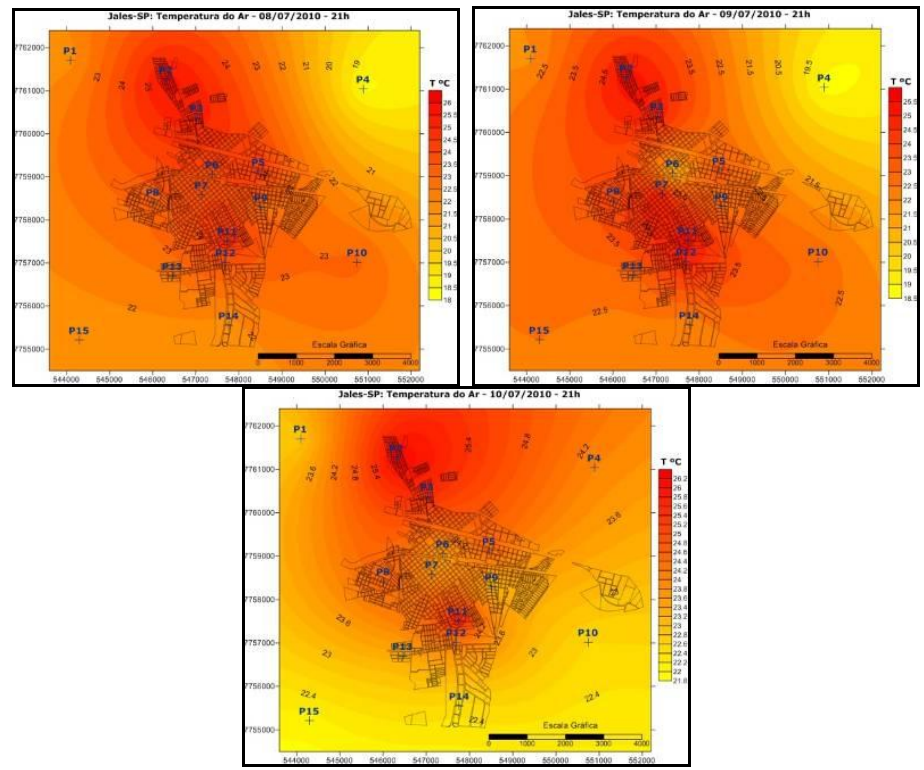

Figuras 35A, 35B e 35C: Temperatura do Ar para os dias 8, 9 e 10/07/2010, 21h.

No dia 12 ocorreu a aproximação do primeiro sistema frontal (figura 37), já descrito anteriormente, com aumento de nebulosidade - observado na Figura 36, causando certa instabilidade atmosférica a partir desse horário, contribuindo para a queda da diferença térmica para $2,3^{\circ} \mathrm{C}$, assim como a temperatura, variando entre 24,3 e $26,5^{\circ} \mathrm{C}$ (Figura 38). A diferença higrométrica também registrou uma queda, ficando em $12 \%$, variando entre 44 e $56 \%$ (Figura 39).

Devido a essa mudança sinótica ocorreram alterações significativas, principalmente em relação à área urbana, pois a zona rural permaneceu menos aquecida, destacando-se os pontos 1 e 15 por apresentarem a temperatura mais baixa $24,3^{\circ} \mathrm{C}$. No espaço intraurbano observou-se três ilhas de calor, sendo que as do ponto 2 e 11 se mantiveram como no dia anterior, surgindo mais uma no ponto 13 , com 26,5, 26,2 e 25,90 $\mathrm{C}$ respectivamente. No centro da cidade (P6 e P7) surgiu uma ilha fresca com $24,5^{\circ} \mathrm{C}$ (Figura 38). Esse padrão se manteve até o dia 17 em função da instabilidade causada pela atuação de um sistema frontal estacionário localizado sobre a região de Jales como será visto mais adiante. 


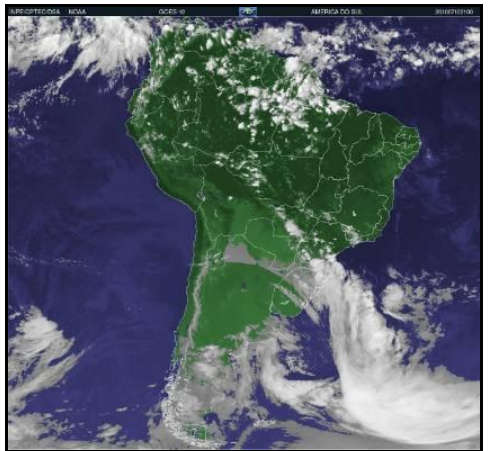

Figura 36: Imagem Goes 12/07/2010, 21h.

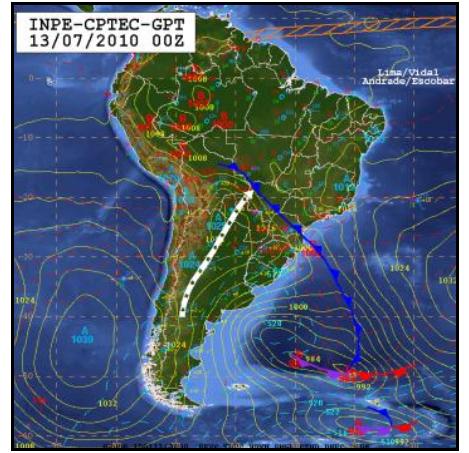

Figura 37: Carta Sinótica 12/07/2010, 21h.

Na Figura 39, nota-se que a zona rural permaneceu mais úmida do que a área urbana, com exceção do ponto 10 . Houve a formação de duas ilhas secas, a primeira no ponto $3 \mathrm{com} 44 \%$ de umidade, e a segunda no ponto 11 , estendendo-se até ao ponto 10 a leste e ao ponto 14 a sul, com $48 \%$ de umidade. Esse padrão também se manteve durante os dias 13 a 17.

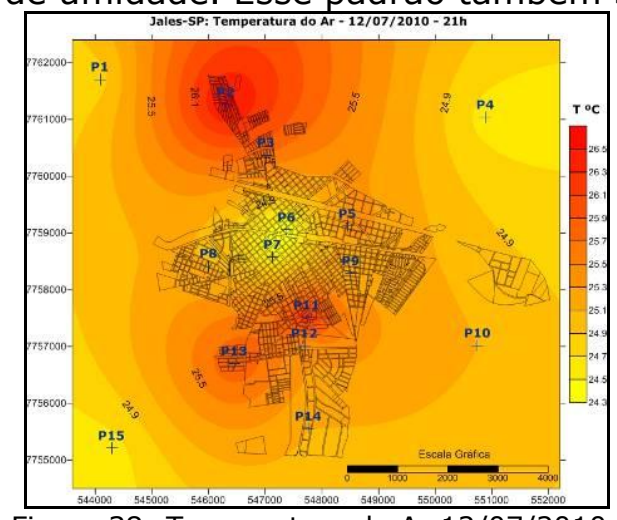

Figura 38: Temperatura do $\operatorname{Ar} 12 / 07 / 2010,21 \mathrm{~h}$.

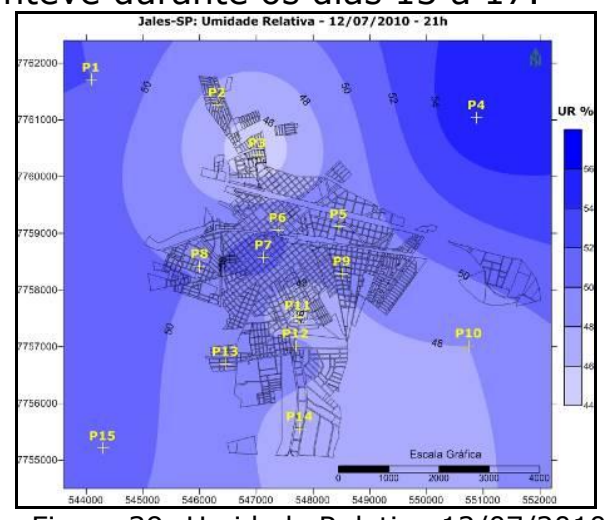

Figura 39: Umidade Relativa 12/07/2010,

Na Figura 40A é possível observar o sistema frontal estacionário sobre a região de Jales. Esse sistema causou instabilidade atmosférica, que contribuiu para a quebra do padrão observado até o dia 11. A alteração mais significativa foi exatamente o surgimento de uma ilha fresca no centro da cidade (P6 e P7). A explicação para essa ocorrência está relacionada com a velocidade dos ventos, que teve aumento expressivo durante esse período, além é claro da direção do vento (NE) que foi responsável por carregar o ar mais aquecido do centro para a área sudoeste do mapa, ponto 13, que apresentou ilhas de calor em todos esses dias (Figura 40B). 


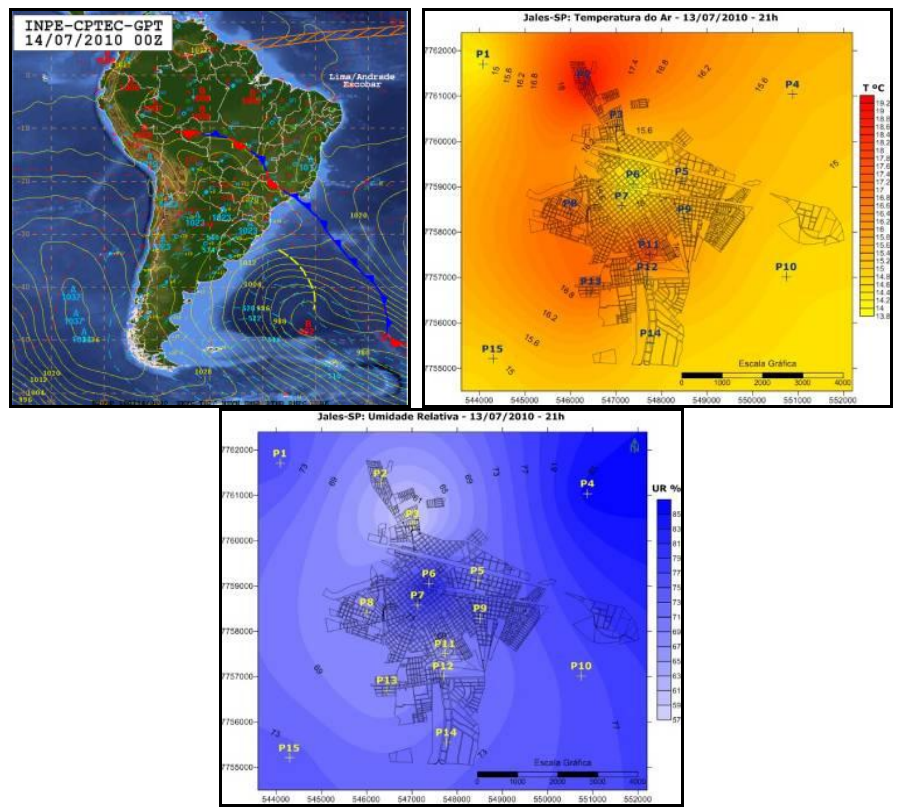

Figuras 40A, 40B, 40C: Carta Sinótica, Temperatura e Umidade Relativa 13/07/2010, 21h.

A umidade relativa também seguiu um padrão bem definido, sendo que se observou a zona rural mais úmida do que a área urbana, além do surgimento de uma ilha seca no ponto 2 e outra úmida no ponto7 (Figura 40C).

A partir do dia 19 a situação sinótica voltou a ser de estabilidade, permitindo maior aquecimento da área, a diferença térmica voltou a subir. O padrão observado pode ser assim descrito: a zona rural se apresentou em todos esses dias menos aquecida, com destaque para o ponto 1 e 4 que apresentaram os menores valores de temperatura em todos os dias analisados, ficando em média com $19,0^{\circ} \mathrm{C}$. Podem ser observadas ilhas de calor nos pontos 2 e 11 em todos os dias, entretanto, dependendo da intensidade dessas ilhas elas se estenderam até outros pontos. Nota-se também o surgimento de outra ilha de calor no ponto7 (centro) sempre ligada ao ponto 11. Em alguns episódios de aquecimento mais significativos ocorreu o aquecimento de diversos pontos dentro da área urbana, sendo que a temperatura foi decaindo em direção a zona rural. Em alguns episódios houve a formação de outra ilha de calor no ponto 13.

É possível observar o aparecimento de uma ilha fresca no ponto 6 (centro residencial) com algumas variações de intensidade, ora estando mais alongada atingindo o ponto 7 , ora mais retraída.

Em linhas gerais esses foram os principais padrões observados no mês de julho, assim como suas principais causas.

\section{CONSIDERAÇÕES FINAIS}

Conclui-se que a cidade de Jales apresenta variações térmicas intraurbanas e uma configuração específica em relação à temperatura e umidade, destacando-se também as diferenças térmicas e higrométricas entre a área urbana e seu entorno rural próximo. As variações registradas para o mês de janeiro foram de $1,2^{\circ} \mathrm{C}$ no dia 27 à $7,4^{\circ} \mathrm{C}$ no dia 4 às $21 \mathrm{~h}$. Já para 0 
mês de julho as diferenças térmicas variaram entre $2,2^{\circ} \mathrm{C}$ no dia 16 de à $8,8^{\circ} \mathrm{C}$ no dia primeiro às $21 \mathrm{~h}$. Diferenças térmicas significativas, na casa de $10^{\circ} \mathrm{C}$, foram encontradas em vários episódios, entretanto, destaca-se que o mês de janeiro foi um mês com precipitação acima do normal, como destacado pelo CPTEC, fato que causou uma diminuição da magnitude das variações registradas em vários episódios. Já o mês de julho apresentou precipitação e umidade relativa abaixo da média climatologia normal.

Destaca-se a área centro-norte como área densamente construída, porém, bem arborizada, e que apresenta as temperaturas mais amenas, e as áreas a leste, sul, oeste, e em alguns episódios os conjuntos habitacionais Arapuã e JACB, como áreas de temperaturas mais elevadas.

A princípio as diferenças térmicas parecem estar relacionadas ao padrão das construções, ao tamanho dos lotes e ao tipo de cobertura, além da existência ou ausência de vegetação urbana.

A partir da caracterização climática, é possível retomar a discussão acerca do planejamento urbano. Sendo o clima um dos elementos do ambiente, ele deve ser levado em consideração para a realização desses processos, e a caracterização apresentada pode ser utilizada como base de dados, pois devidamente cartografada destaca as áreas que apresentam problemas, com queda na qualidade ambiental, e as áreas mais adequadas para ocupação. Essa informação deve ser adicionada ao planejamento urbano, sendo mais um suporte de dados para a tomada de decisões.

Através da caracterização climática, foi possível relacionar variação da temperatura e a formação de ilhas de calor ou ilhas frescas com os demais elementos do meio, além de fatores urbanos, como a presença ou ausência de vegetação, e a densidade de ocupação. Essa correlação permite identificar as causas dos problemas encontrados e suas possíveis soluções. Os dados e as análises apresentadas neste artigo permitem compreender de maneira mais detalhada o microclima da cidade de Jales bem como suas causas. Destaca-se que cabe ao poder público municipal - por ser o responsável pelo planejamento e pela gestão do espaço - incorporar essas informações aos seus processos de planejamento urbano, por ser mais uma forma de diagnostico e análise de indicadores ambientais.

De maneira mais pragmática os dados apresentados permitem diagnosticar problemas relacionados ao clima urbano e direcionar ações que visem suas soluções. À longo prazo, esses dados, desde que sejam incorporados aos processos de planejamento e atualizados periodicamente, colaboram com a identificação prévia de possíveis problemas nas futuras áreas a serem ocupadas, permitindo ações preventivas que evitem o surgimento do problema. Em ultima análise, o Poder Público tem sua capacidade de ação ampliada por ter a sua disposição o conhecimento detalhado do problema, fato que permite a melhoria da qualidade ambiental e da qualidade de vida, através da gestão ambientalmente adequada do meio urbano.

\section{REFERÊNCIAS}

.AMORIM, M.C.C.T. O clima urbano de Presidente Prudente/SP. São Paulo, 2000. 378p. Tese(Doutorado em Geografia) - Faculdade de Filosofia Letras e Ciência Humanas - USP.

.ANDRADE, H. O Clima Urbano - natureza, escalas de analises e aplicabilidade. Revista Finisterra, no 80,2005 , p.67-91 
.BRANDÃO, A. M. de P. M. O clima urbano da cidade do Rio de Janeiro. São Paulo, 1996. 362p. Tese (Doutorado em Geografia Física) - Faculdade de Filosofia Letras e Ciências Humanas, Universidade de São Paulo.

.GRAZIANO NETO, F. Questão agrária e ecologia crítica da moderna agricultura. 2.ed. São Paulo: Brasiliense, 1985.

.LOCATEL, C. D. O Desenvolvimento da Fruticultura e a Dinâmica da Agropecuária na Região de Jales-SP. 2000, 272p. Dissertação (Mestrado em Geografia) - Faculdade de Ciências e Tecnologia, Universidade Estadual Paulista, Presidente Prudente.

.LOMBARDO, M. A. Qualidade ambiental e planejamento urbano: considerações e método. São Paulo, 1995. Tese (Titulo de Livre Docência em Geografia Física) - Faculdade de Filosofia, Letras e Ciências Humanas, Universidade de São Paulo.

.MENDONÇA, F. de A. O clima e o planejamento urbano de cidade de porte médio e pequeno: proposição metodológica para estudo e aplicação à cidade de Londrina, PR. São Paulo, 1994. 322P. Tese (Doutorado em Geografia Física) - Faculdade de Filosofia, Letras e Ciências Humanas, Universidade de São Paulo.

.MONBEIG, P. Pioneiros e Fazendeiros de São Paulo: São Paulo: HUCITEC, 1984.

.MONTEIRO C. A. de F. Teoria e Clima Urbano. São Paulo, IGEOG/USP, 1976, 181p.

.MONTEIRO, C. A. de F. e MENDONÇA, F de A. (org). Clima Urbano: São Paulo: Contexto, 2003. 192p.

.MOTA, S. Urbanização e Meio Ambiente. Rio de Janeiro: ABES, 1999. 353p.

.NARDOQUE, S. Apropriação Capitalista da Terra e a Formação da Pequena Propriedade em Jales-SP. 2002, 304p. Dissertação (Mestrado em Geografia) - Faculdade de Ciência e Tecnologia, Universidade Estadual Paulista, Presidente Prudente.

.OZBEKHAN, H. Rumo a uma Teoria Geral de Planejamento. Simpósio sobre "previsões de longo prazo e planejamento", realizada em Bellagio (Lago de Como). 1968.

.SOUZA, M. L. de. ABC do Desenvolvimento Urbano. Rio de Janeiro: BERTRAND BRASIL, 2003. 190p.

.SOUZA, M. L. de. Mudar a Cidade: uma introdução ao planejamento e à gestão urbanos. Rio de Janeiro: BERTRAND BRASIL, 2002. 560p.

.UGEDA JUNIOR, J.C. Qualidade Ambiental e Planejamento da Paisagem na Cidade de Jales-SP. Presidente Prudente-SP. 2007, 206p. Dissertação (Mestrado em Geografia) Faculdade de Ciências e Tecnologia, Universidade Estadual Paulista, Presidente Prudente.

Sites.

BRASIL, (Centro de Previsão de Tempo e Estudos Climáticos) CPTEC . Disponível em: <http://www.cptec.inpe.br>

BRASIL, (Instituto Brasileiro de Geografia e Estatística). IBGE - Cidades@ Disponível em: <http://www.ibge.gov.br>. Acesso em 18/04/2007.

BRASIL, (Marinha do Brasil) Disponível em: <http://www.mar.mil.br>.

Prefeitura Municipal de Jales. Disponível em <http://www.jales.sp.gov.br>. 